\title{
NEZNÁMA (HERECKÁ) TVÁR JANKA BORODÁČA
}

\author{
KAROL MIŠOVIC
}

Ústav divadelnej a filmovej vedy Centra vied o umení Slovenskej akadémie vied, Bratislava

\begin{abstract}
Abstrakt: Pri hodnotení práce zakladatel’skej osobnosti slovenského divadelníctva Janka Borodáča sa najväčší dôraz oprávnene kladie na jeho režijnú, dramaturgickú a riaditel'skú činnost́. No popri tom bol Borodáč viac než dvadsat rokov aj aktívnym členom hereckého ansámblu Slovenského národného divadla, kde nadobudol výrazné postavenie. Ciel’om štúdie je predstavit nielen dodnes prehliadaný až marginalizovaný záber na jeho herecký profil, ale aj charakterizovat' kontext zmätočnej prevádzky úvodných rokov existencie SND, v ktorých pracovala prvá generácia slovenských profesionálnych hercov. S hereckou tvorbou súvisí i Borodáčova práca ako pedagóga. Vd’aka nemu vznikol na Hudobnej škole v Bratislave dramatický odbor, prvý tohto zamerania na Slovensku, kde ako pedagóg vychovával d’alšie generácie slovenských umelcov. Podobne ako v réžii a herectve, aj v pedagogickej činnosti vyžadoval od študentov osvojenie si psychologicko-realistickej metódy a striktne odmietal akýkolvek prejav antiiluzívnej štylizácie.
\end{abstract}

Kl'účové slová: Janko Borodáč, Slovenské národné divadlo, Konstantin Sergejevič Stanislavskij, herectvo, pedagogická činnost

\section{Borodáč ako herec}

Podl’a českého divadelného historika Františka Černého sa význam režiséra ako vedúcej osobnosti divadelného diela začal výraznejšie pripomínat’ až koncom 18. storočia, aj ked’ sa s jeho funkciou (i ked' nie pod týmto názvom a v tom postavení ako ho poznáme dnes) stretávame už v časoch antického divadla. „V názore na režisérsku prácu dochádza však v dôsledku viacerých príčin divadelného i spoločenského charakteru k vel’mi vážnym zmenám. S plnou silou sa tento proces v európskom divadelníctve presadí až v druhej polovici 19. storočia a predovšetkým v 20. storočí. “1

Podobne to bolo aj v českom divadelníctve, t. j. v nám kultúrne najbližšom kontexte, kde až do záveru druhej polovice 19. storočia patrilo určujúce a pre javiskový tvar zvrchované postavenie hereckým protagonistom. V Čechách považujeme za prvých režisérov v skutočnom zmysle slova Josefa Šmahu, Edmunda Chvalovského a Františka Kolára, tvoriacich na prelome 19. a 20. storočia. No až pri Jaroslavovi Kvapilovi sa dá hovorit’ o modernej réžii, ktorá sa snažila nielen zosúladit všetky scénické zložky do koherentného celku, ale inscenáciu aj významovo interpretovat'. Kvapil zároveň ako prvý režisér v českej divadelnej histórii nevychádzal z hereckej autopsie, bol prvým režisérom-nehercom. Dovtedy, ale aj neskôr bolo v divadle totiž zvykom, že sa režisérmi stávali najskúsenejší herci súboru. Obdobne ako na Slovensku v prípade Janka Borodáča.

\footnotetext{
${ }^{1}$ ČERNÝ, F. Otázky divadelní režie. Praha : Melantrich, 1988, s. 39. Z češtiny preložil K. M.
} 
Ak nepočítame Borodáčovu ochotnícku tvorbu na východoslovenskom vidieku a jeho zriedkavé návštevy mad’arských inscenácií v Prešove a Košiciach, s profesionálnym divadlom sa po prvýkrát zoznámil až počas štúdia na dramatickom odbore pražského konzervatória (1919 - 1921). Do Prahy teda prišiel bez znalostí o divadelnej histórii, teórii, estetike alebo rozvetvenosti súčasného scénického umenia. Počas dvoch rokov strávených $\mathrm{v}$ hlavnom meste republiky mal bohaté možnosti tieto nedostatky dobehnút. No najväčší vplyv na vyprofilovanie umeleckého svetonázoru ambiciózneho Prešovčana nemali tunajšie hostovania zahraničných súborov či pestrofarebná dramaturgia pražských kamenných divadiel, ale pedagógovia. Zvlášt jeho - dnešným slovníkom povedané - ročníkový vedúci Jaroslav Hurt, niekdajší dvorný herec Jaroslava Kvapila (napr. predstavitel' Kulygina v inscenácii Čechovovej hry Tri sestry, ktoré Kvapil režíroval podla Stanislavského režijnej knihy z roku 1901) a rigorózny zástanca idey „divadlo hercom“, teda názoru, že dobrý režisér môže vzíst len z praktickej hereckej skúsenosti. Hurt učil Borodáča abecede hereckého remesla, ktorá spočívala v oboznámení sa s metódou psychologického realizmu v duchu Moskovského umeleckého akademického divadla, postavenej na vyvolaní nefalšovanej atmosféry pravdy, citu a nálady. No ani ako herec, ani ako pedagóg nikdy neprekročil obzory iluzívneho typu divadla. $\mathrm{V}$ tom ho nasledoval aj jeho verný študent Borodáč. ${ }^{2}$

Prvé profesionálne kroky mladého herca Janka Borodáča mapujeme v roku 1921, ked' prijal prvé angažmán. So spolužiakmi z Prahy - Karlom Balákom, Ol'gou Országhovou, Jaroslavom Tumlírom a Mariou Slámovou - nastúpili do zájazdovej spoločnosti SND II., tzv. Maršky, ktorej ciel’om bolo „šírit lásku k slovenskému jazyku a k slovenskej kultúre “3. Ansámbel sa skladal z devätnástich členov, z toho iba piatich Slovákov (Gašpar Arbét, Andrej Bagar, Janko Borodáč, Jozef Kello, Ol'ga Országhová), medzi ktorými si Borodáč vydobyl výnimočné postavenie. Z kvinteta bol najčinorodejší, najciel'avedomejší a po dvoch rokoch strávených v Prahe pravdepodobne aj divadelne najrozhladenejší. V Marške stvárnil dvadsat’ úloh najrôznejšieho typu, žánru i rozsahu. V premiérovej inscenácii SND II., Palárikovom Inkognite (1. 10. 1921), vytvoril ústrednú postavu, intrigána Potomského. K väčším úlohám patrili i hypochondrický ženích Lomov v Čechovových Pytačkách (18. 10. 1921), horlivý dohadzovač Kočkarev v Gogol'ovej Ženbe (10. 10. 1921) alebo egocentrický doktor Rank v Ibsenovej Nore (14. 2. 1922). Zvyšok Borodáčovho repertoáru tvorili stredné vel'ké, prípadne skôr zanedbatel’né figúrky. Kvalitu jeho výkonov je však t’ažké posúdit', ked’že sa nezachovali žiadne objektívnejšie či aspoň obšírnejšie hodnotenia. Vynára sa tiež otázka, či obsažné úlohy nedostal len pre svoju národnostnú príslušnost'. Iba devät’ z dvadsiatich piatich premiér Maršky sa totiž hralo v slovenčine ${ }^{4}$, s ktorou mali - od Borodáča herecky skúsenejší - českí kolegovia výrazné problémy. V inscenáciách naštudovaných po slovensky boli preto do väčších úloh obsadzovaní slovenskí herci, aj napriek tomu, že ešte umelecky nevyspeli. V provizórnej prevádz-

\footnotetext{
${ }^{2}$ Viac o kontextoch štúdia Janka Borodáča pozri MIŠOVIC, K. Ján Borodáč a jeho prvé kroky v živote i v divadle. In Slovenské divadlo, 2017, roč. 65, č. 2, s. $101-120$.

${ }^{3}$ KÜHN, L'. Slovenské národné divadlo. In Slovenský svet, 1921, roč. 1, č. 29 - 30, s. 21 - 22, 13. 11. 1921. Cit. podla PAŠUTHOVÁ, Z. - HUDEC, R. Marška. Denník Karla Baláka. Bratislava : Divadelný ústav, 2011, s. 30 .

${ }^{4}$ Janko Borodáč a d’alší štyria slovenskí členovia Maršky hrali ostatný repertoár v českom jazyku.
} 
ke, v ktorej Marška existovala, je viac než pravdepodobné, že režisérom Vladimírovi Jelenskému a Vilémovi Táborskému išlo v prvom rade o rýchlost’ tvorby repertoáru, nie o jeho kvalitu. To sa týkalo aj práce na hereckej zložke inscenácií, takže sa dá len t’ažko špecifikovat’ naturel a typológia Borodáča ako začínajúceho herca, nehovoriac o úrovni jeho umenia.

Borodáčove herecké dispozície sa mohli plnšie rozvinút’ až od roku 1924, ked' s manželkou Ol'gou Borodáčovou Országhovou získali angažmán v hereckom súbore činohry SND. Riaditel' divadla Oskar Nedbal ich prijal, podobne ako zvyšných troch slovenských členov bývalej Maršky, kvôli silnejúcim novinárskym hlasom, ktoré volali po nutnosti poslovenčenia činohernej produkcie. A to nebolo možné bez Slovákov, s ktorými mohli režiséri jednoduchšie naštudovat’ repertoár v ich rodnom jazyku. Borodáča okamžite po príchode poverili aj režírovaním slovenských inscenácií. Zopakovala sa historická skutočnost', že najagilnejší členovia hereckého súboru sa stávajú režisérmi.

Od tohto momentu môžeme sledovat’ svojbytný vývoj slovenského činoherného slohu, ktorého nestorom je práve Janko Borodáč. Popri režijnej, prekladatel’skej a dramaturgickej práci vykonával nad’alej i herecké povolanie, ktoré bolo jeho hlavnou zamestnaneckou náplňou. Borodáča a jeho slovenských kolegov začali režiséri okamžite po príchode aktívne obsadzovat', pravidelne dostávali príležitosti aj v tažiskových postavách. No vysoká kvantita diel v repertoári mala často negatívny vplyv na kvalitu inscenácií. V rýchlom slede premiér, ked’ skúškové obdobie trvalo necelé dva týždne a inscenácie dosahovali optimálne pät’ až desat' repríz, si herci iba t’ažko osvojovali dramatické úlohy. Nielen slovenskí, aj skúsenejší českí protagonisti sa uchylovali k hereckému klišé, povrchnosti a ilustratívnej deklamácii. Zisková obozretnost’ súkromného podniku, akým bolo medzivojnové SND, utláčala tvorivý proces. Ako sumarizoval divadelný teoretik Miloš Mistrík: „Často sa diváci stretávali s figúrkami, zjednodušenými a jednostrannými interpretáciami postáv. Ak išlo o typy l'udové, slovenskí herci ich hrali síce s láskou, ale aj so sklonom k folklorizovaniu a junáctvu, niekedy k nadmernej komike. Typy salónne či mestské zase predstavovali iné klišé: herci sa zmietali v naklonených psychických stavoch, v rozporuplných položeniach. Na náročnejšiu prácu niekedy jednoducho nezvyšovalo času, príkre prevádzkové podmienky a rýchly sled premiér vyčerpával aj tých najtalentovanejších. " ${ }^{25}$

Herci museli v krátkom časovom horizonte účinkovat’ v inscenáciách rôznych žánrov, stvárnit’ rozmanité charaktery a typy, umelecky zachytit pestré emočné polohy. Ale počas skúšok „,dostávali len tie stránky hry, na ktorých mali text, a réžia predstavovala iba základné aranžmán, pričom herecká tvorba sa zredukovala prevažne na schopnost’ naučit’ sa (so šepkárovou pomocou) text a nájst̉ jednoduché a výrazné typologické znaky, ktoré umožnili divákom jednoznačne si postavu zaradit’ (...)“. ${ }^{6}$ V súbore koexistovali slovenskí a českí umelci, ktorých spoločný počet neprekračoval číslo dvadsat. Pri českých hercoch navyše dochádzalo k pravidelným prestupom na lukratívnejšie pôsobiská v Prahe, Brne, Olomouci či Plzni. Z dôvodu neustávajúcej fluktuácie museli zostávajúci členovia súboru hrat’ doslova všetko, čo prišlo. Preto nedochádzalo k prenikavejšej profilácii jednotlivých hercov a k režijno-dramaturgickému cizelovaniu prirodzených typologických daností ich hereckého naturelu.

\footnotetext{
${ }^{5}$ MISTRÍK, M. Analýzy hereckej syntézy. Bratislava : Thália-press, 1995, s. 8.

${ }^{6}$ MAŤAŠÍK, A. Cesty slovenského herectva. In Slovenské divadlo, 2008, roč. 56, č. 1, s. 16.
} 


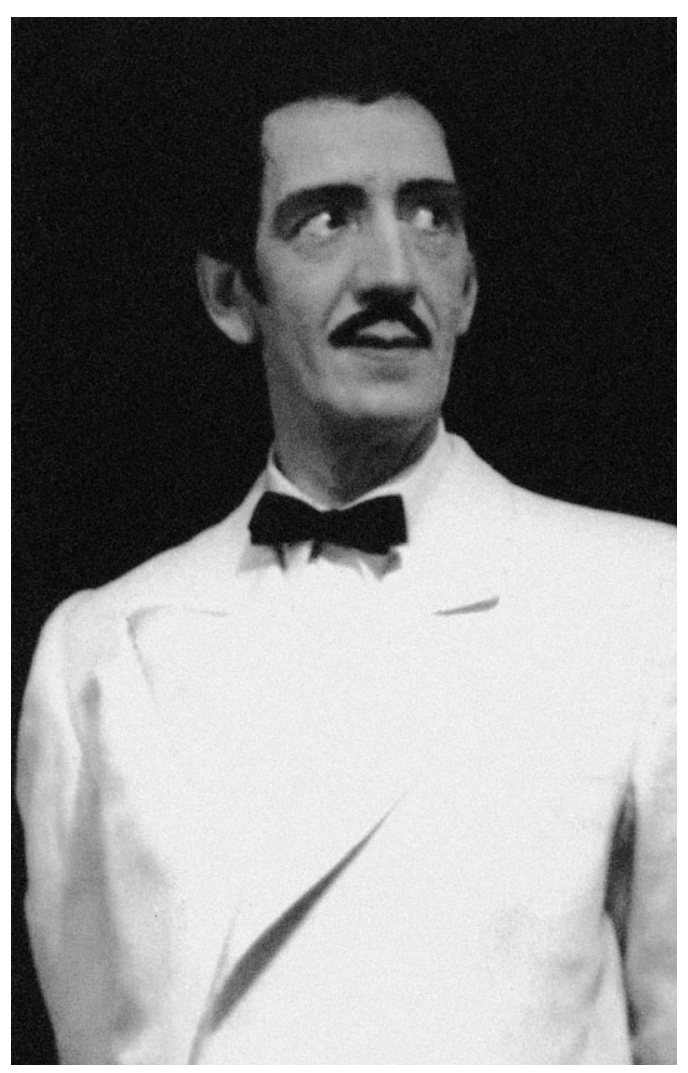

Ivo Vojnović: Dáma so slnečnicou. Slovenské národné divadlo, premiéra 30. 11. 1928. Réžia Janko Borodáč. Janko Borodáč (Goljukov). Foto archív SND.

Ťažiskové úlohy hrávali najmä rutinovaní umelci, ktorým nerobilo problém stvárnit’ so stereotypne zažívanými prostriedkami aj textovo rozsiahle a emočne náročné roly. Z mužov Slovákov si výnimočné herecké postavenie už od začiatku angažmánu vydobyl práve Janko Borodáč. Paradoxne, Andrej Bagar - budúci prvý slovenský profesionálny Hamlet, Macbeth, Cyrano či Tartuffe - sa v dvadsiatych rokoch dostával v porovnaní s Borodáčom k podradnejším rolám, preto z nedostatku príležitostí v období 1925 - 1927 zvolil pôsobenie mimo SND. ${ }^{7}$

Z dnešného hl'adiska už nie je možné rekonštruovat', či bola Borodáčova dominancia v súbore zdôvodnená najprecíznejšie zvládnutou javiskovou slovenčinou, výraznou mužskou typológiou (takmer dva metre vysoká postava, mierne pretiahnutá tvár s ostro rezanými črtami) a ciel'avedomými ambíciami, alebo Borodáčove herecké kvality skutočne prevyšovali vtedajší slovenský priemer. Pri neúprosnom kolobehu premiér a nízkom počte členov súboru pravidelne dochádzalo i k tomu, že sa musel obsadit’ do ním režírovanej inscenácie. Samozrejme, do úvahy môžeme zobrat’ i fakt, že "sebaobsadenie“ mu šetrilo čas, nakol'ko sám najlepšie vedel naplnit’ predstavy svojho režijného zámeru. Ako s hercom s ním však programovo spolupracovali aj

${ }^{7}$ Andrej Bagar bol v rokoch 1925 - 1926 členom novovzniknutého Východoslovenského národného divadla v Košiciach a v období 1926 - 1927 pôsobil vo Východočeskom divadle v Pardubiciach. 
ostatní režiséri súboru - Bohuš Hájek, Vladimír Šimáček či Václav Jiřikovský. Najmä posledný menovaný, šéf činohry v rokoch 1925 - 1929, patril k progresívnym českým tvorcom a svojimi dramaturgickým i režijnými činmi sa snažil o vzostup činoherného telesa SND aspoň na solídnu celorepublikovú úroveň, čo sa mu aj v značnej miere darilo. Ak by totiž Borodáč nezodpovedal jeho režijným víziám, zrejme by si ho nedovolil obsadit do klúčových rol reprezentačných inscenácií, či už v českom alebo slovenskom jazyku. Pod Jiřikovského vedením mal začínajúci herec Borodáč možnost' stvárnit’ najmä charizmatických mužov bojovného až extrovertného naturelu - titulných hrdinov v Mahenovej rovnomennej tragédii Jánošík (18. 9. 1925) a v Hviezdoslavovej básnickej dráme Herodes a Herodias (27. 11. 1925), metafyzického Lucifera v Madáchovej Tragédii človeka (11. 12. 1926) či balkánskou spiritualitou presiaknutého Damjana v Begovićovom Božom človeku (2. 9. 1927).

Jednou z prvých Borodáčových hlavných úloh v SND bola titulná postava v ním režírovanej inscenácii Molièrovej komédii Juraj Dandin (18. 9. 1924). Kritika výkon jednoznačne vyzdvihla a konštatovala, že „,v jeho úsmevoch bolo mnoho prvkov súčasne: bezvadnost', nevinnost', zúfalstvo, tázavost’ - to je už herecká schopnost'. “8 Táto kritická reflexia sa napriek svojej vágnosti zarad’uje k najkonkrétnejším, s akými sa herci v prvých rokoch SND stretávali. ${ }^{9}$ Pri kontinuálnom čítaní dobových recenzií Borodáčových výkonov vystúpia však do popredia opakujúce sa výhrady voči jeho nedôslednej artikulácii a málo plastickej práci s hlasom. Takto motivovanú kritiku si vyslúžil najmä najväčšou hereckou príležitostou - Herodesom v Hviezdoslavovej mocenskej tragédii. Kritici sa v pohl'ade na Borodáčove charakterizačné schopnosti názorovo rozchádzali: $\mathrm{v}$ recenziách sa stretneme s rigoróznym odmietnutím, aj s jednoznačným akceptovaním výkonu. Jednohlasne sa však zhodli na nezvládnutej práci s hlasovou a artikulačnou technikou, pretože nebol schopný pestrejšej modulácie. ${ }^{10}$ Na základe kritického a fotografického materiálu sa dá usudzovat', že Borodáč nestvárňoval galilejského tetrarchu ako autoritatívneho muža pevného gesta, v zmysle výkladu roly i konkrétneho hereckého prostriedku. V celkovom pohlade ho vyložil ako submisívneho vladára, pričom v pasážach exaltovanej vášne a prudkých emočných zlomov upadal do preexponovanej kŕčovitosti. No hlavným nedostatkom výkonu bol prednes Hviezdoslavovho verša. Literátka a kritička Hana Gregorová konštatovala: „Nevadí, že bol málo král'ovský, on podal túto postavu individuálnym právom herca viac l'udsky. Dobrá bola intonácia hlasu, prechody z vášne v skleslost’

${ }^{8}$ H.G. [Hana Gregorová]. Nútená svadba. 1924. Čiastočne identifikovaný článok sa nachádza v inscenačnej obálke Juraj Dandin/Nútená svadba, premiéra 18. 9. 1924. In Zbierka inscenácií, Divadelný ústav v Bratislave. Pri všetkých citáciách z dobovej tlače je zachovaný ich pôvodný pravopis.

${ }^{9}$ Slovenská divadelná kritika bola len na začiatku svojej existencie, preto o inscenáciách často referovali žurnalisti bez osobitejšieho umeleckého vzdelania. O premiérach v jedinom profesionálnom slovenskom divadle sa síce písalo pravidelne a redaktori im v novinách často vyčleňovali rozsiahly priestor, ale autori statí venovali najväčšiu pozornost’ analýzam hier (resp. prerozprávaniu deja), k charakteristike jednotlivých komponentov sa vyjadrovali iba v minimálnej miere. Málokto z nich dokázal plasticky pomenovat’ špecifiká režijnej práce, výtvarnej stránky či hereckých výkonov. Preto bola tvorba divadelníkov hodnotená prostredníctvom všeobecných charakteristík, z ktorých síce vyplývali jasné názorové stanoviská (aj ked' málokedy podopreté divadelno-estetickými základmi), ale nie kompetentná spätná väzba. Preto je dnes náročné rekonštruovat’ jednotlivé herecké výkony, ked’že sa bud’ nezachovala ich odborná reflexia, alebo tá existujúca odráža výsostne subjektívny (často i politicky zafarbený) názor. Pozitívne ohlasy na výkony slovenských hercov boli často manifestáciou autorov recenzií horliacich za poslovenčenie divadla, prípadne článkami politicky činných kultúrnych predstavitel’ov.

${ }^{10}$ [Bez autora]. Herodes a Herodias. In Slovenský denník, 1925, roč. 8, č. 271a, s. 3, 29. 11. 1925. 


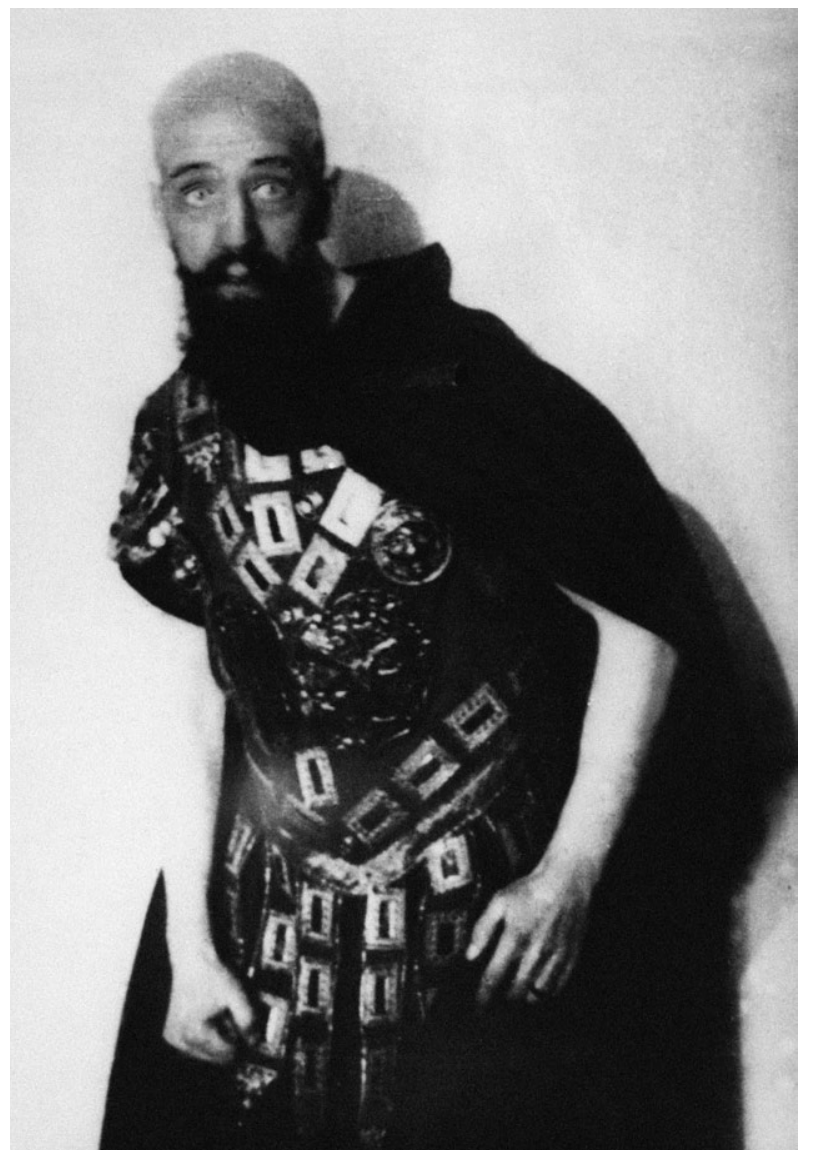

Pavol Országh Hviezdoslav:

Herodes a Herodias. Slovenské národné divadlo, premiéra 27. 11. 1925. Réžia Václav Jiřikovský. Janko Borodáč (Herodes). Foto archív SND.

z únavy a zase vo vášne, i že bol len ohlasom Herodias, charakterove správne podal. - Ale čo je to platné, ked' Hviezdoslavovu reč neprednášal tak, aby mu rozumelo celé divadlo. Zato nesprávne nel’udským hlasom kričal, kde mal dramaticky prednášat.." ${ }^{11}$ Borodáč si nesúlad medzi životaschopným Herodesom z pôvodného textu a vlastným hereckým výkladom uvedomoval. Z neúspechu i desat'ročia po premiére obvinil režiséra Jiřikovského: „Hral som Herodesa v kostýme s holými nohami a ramenami, vyziabnutý, schudnutý, ako podlomený konár. (Bol to Herodes, akého by som ako režisér na javisko nepustil). " ${ }^{22} \mathrm{~V}$ tom možno s interpretom len súhlasit', i ked' nedostatočná zrozumitel'nost’ bola výsostne jeho hereckým problémom.

Kreácia Herodesa potvrdila predpoklad, že Borodáč herecky neinklinoval k vodcovským postavám, skôr k ich opaku. Jeho vysoký vzrast, komótna telesná energia i slabý hlas neschopný pestrejšej intonačnej modulácie mu nedovol'ovali stvárňovat’ postavy letorou buričské, hedonistické, excentrické ani rezonérske. Naopak, boli mu

${ }^{11}$ H.G. [Hana Gregorová]. Hviezdoslavov Herodes. In Robotnícke noviny, 1925, roč. 22, č. 299, s. 5, 29. 11. 1925.

${ }^{12}$ BORODÁČ, J. Spomienky. Bratislava : Národné divadelné centrum, 1995, s. 111 - 112. 
blízke roly vzdelancov, indiferentných introvertov, ale i l'udí osobnými danostami prevyšujúcich prízemnost' svojho okolia. Z tohto dôvodu v Urbánkovej l'udovej dráme Rozmajrín (31. 8. 1925) stvárnil urodzeného grófa Imricha Lipianskeho a nie niekoho z vidieckej masy, v Gogol’ovej Ženbe (8. 10. 1926) sa zase sám obsadil do roly delikátneho ženícha Anučkina, nie niektorého z d’alších, impulzívnejších a typológiou animóznejších pytačov. No pri všetkých výhradách, v kvantitatívne i kvalitatívne obmedzenej slovenskej časti činoherného súboru SND to bol práve Janko Borodáč, kto dokázal aspoň na solídnej úrovni stvárnit’ náročné domáce aj inonárodné mužské postavy v pestrom žánrovom rozpätí. Po návrate do Bratislavy však prebral vedúce postavenie v slovenskej časti hereckého súboru Andrej Bagar. Jozef Kello sa preukazoval ako vyhranený predstavitel' žánrových figúrok, psychologicky nenáročných úloh a karikatúrno-komických typov, ale na rozdiel od Borodáča a Bagara nikdy nedospel k méte charakterového herca.

Borodáčovo herectvo sa na prelome dvadsiatych a tridsiatych rokov definitívne vycizelovalo pre postavy chladných intelektuálov, aristokratov a bizarných spoločenských persón. Vyhovovali mu predovšetkým roly asociálov, kategoricky súdiacich spoločnost', pretože nezdiel’ala ich morálne hodnoty - takým bol napr. Malvolio v Shakespearovom Večeri trojkrál'ovom (23. 3. 1928), no stále sa tažko „vžíval“ do postáv zemitých, charizmatických, heroických, intímne emocionálnych. Jeho hereckému uspôsobeniu neboli vlastné tóny krehkého citu, ani polohy diskrétneho odhal’ovania vnútorných procesov. Na rozdiel od svojej režijnej práce, v herectve mal problém dosiahnut prirodzené vyznenie molových stupníc hereckej škály.

Napriek tomu sa na prelome decénií pravidelne stretával s postavami autoritatívnych postáv, ktoré pod mužsky neprístupným povrchom skrývajú nejednoznačné l’udské city. Paradoxne sa do takýchto postáv obsadzoval zväčša sám a jeho výkony sa takmer vždy stretli s negatívnou kritickou odozvou. Exemplárnym príkladom môže byt’ rola kniežat’a Alexeja Vronského v dramatizácii Tolstého Anny Kareninovej (14. 9. 1928). Typológia vášnivých milovníkov a elegantných džentlmenov vzbudzujúcich popri úcte aj obdivné ženské pohlady boli Borodáčovi cudzie. Pritom do postavy Anninho odmeraného manžela Karenina obsadil Borodáč Andreja Bagara, pravidelného predstavitel'a seladónov, bohémov a zvodcov s vrodenou anglickou noblesou. Teda herca s atribútmi, s ktorými by Vronského stvárnil prirodzenejšie než Borodáč. Aj kritička Jindra Hušková, podporovatel'ka vzostupu slovenského činoherného umenia, musela konštatovat', že Borodáč bol živelnej Anne v podaní Hany Meličkovej prislabým spoluhráčom. „Škoda, že v našom ensemblu nemáme k nej ešte prípadného Vronského. Obsadenie p. Borodáčom sa nedokázalo [autorka mala zrejme na mysli slovo neosvedčilo - pozn. K. M.] a je škoda, že sa tento herec, ktorého odbor treba hl'adat', ako sme už niekol'kokrát spomenuli, celkom inde, zbytočne exponuje - lebo musí exponovat’ - v podobných úlohách.“"13 Tu s väčšou pravdepodobnostou, ako už neraz, zasiahla režisérova osobná ambícia, pre ktorú precenil vlastné herecké schopnosti.

Ani nasledujúca postava Ondreja zo Stodolovej Bačovej ženy (4. 10. 1928) nepatrila k Borodáčovým vierohodným kreáciám. I ked’ recenzent denníka Slovák s porozumením prijal jeho - na začiatku presného a stručného, v závere drámy temperament-

${ }^{13}$ Beta [Jindra Hušková]. Druhý večer Tolstého osláv. In Slovenský denník, 1928, roč. 8, č. 198, s. 3, 16. 9.1928. 
ného - Amerikána ${ }^{14}$, kritik zo Slovenského diela naopak tvrdil: „(...) citová suchost” a skôr rozumársky a neintuitívne založená povaha jej [Ol'gy B. Országhovej ako titulnej Evy - pozn. K. M.] partnera Borodáča spôsobila, že Ondrej vyhovoval vlastne len v dejstve prvom (ak už máme verit', že z Ondreja, tak plného poetizmu hory a túhy za vlastou, by sa bol stal suchopárny Amerikán), sklamal však vo chvílach tragiky, kde sa mu nedostávalo ani postojove, ani hlasove tragickej híbky. " ${ }^{15} \mathrm{Z}$ dvojice sokov v súboji o srdce bačovky Evy vyšiel úspešnejšie Andrej Bagar ako Mišo, lebo na rozdiel od Borodáča dokázal dodat postave „viacej bezprostredného jímavého citu“16. Kritike neostávalo iné než explicitne pomenovat', že „J. Borodáč bol viac šikovný v režii, ako v hre. To, čo sa o ňom povedalo prv aj dnes by sa dalo potvrdit: je lepším režisérom, dramaturgom i učitel'om svojich žiakov, ako sám hercom. “17

O Borodáčovom nekonzistentnom a typovo ohraničenom herectve sa po rokoch vyjadril aj literát Tido J. Gašpar, ktorý v rokoch 1925 - 1927 vykonával funkciu dramaturga činohry SND. Vo svojich pamätiach pripomenul, že Borodáč bol ambicióznym a odhodlaným divadelníkom, ktorý túžil po zdokonalení sa v hereckom remesle. „Vytrvalost’ a pilnost' viedli ho vždy k lepším a lepším hereckým výkonom. Niektoré svoje úlohy dokonca zvládol potom výborne. V Gregorovej Tme alebo v Hriechu [druhú z menovaných hier počas Borodáčovho pôsobenia v SND neuviedli, Gašpar mal zrejme na mysli inú Tajovského drámu - pozn. K. M.] a vôbec v predstavovaní l'udových a malomestských typov dopracoval sa k skvelým výkonom. Ale nejakým hrdinom lásky alebo rytierskym synom sveta nebol. “18 Ako príklad uvádza Gašpar rolu docenta fyziky Przeleckiho v hre Stefana Żeromského Ulietla mi prepelička (9. 9. 1925), ktorú si vraj Borodáč vynútil, ked’že túžil viac hrat'. No jeho výkon nemal úspech. Opisy Przeleckiho ostatnými postavami totiž „,vybičujú zvedavost̉ divákov, že každý očakáva výstup nejakého prekrásneho syna sveta. L'udia myslia, že sa prinajmenej zjaví nejaký antický poloboh, ktorý všetko oslní. A do toho vel'kého napnutia zrazu len vtrhne - Borodáč. V tom okamihu nastane skoro tragická dezilúzia. Hra je každého kúzla zbavená. L'udia sú sklamaní. Borodáč chodí po javisku a sklamaný divák vytriezvene vzdychá. (...) S podlamujúcimi kolenami nevie ukázat’ ani len trochu imponujúcu postavu. “19 Túto príhodu však Gašpar zrejme neprerozprával celkom exaktne, skôr ide o kombináciu niekol'kých separátnych spomienok. Inscenáciu totiž režíroval samotný Borodáč, preto neznie pravdepodobne, že by prosil dramaturga o svoje obsadenie do hlavnej roly príbehu. Ale disproporcia medzi naturelom osudového muža a Borodáčovými hereckými dispozíciami nastala určite - a dezilúzia divákov, opísaná Gašparom, pravdepodobne tiež.

Na rozdiel od realistických rol sa Borodáč dokázal uplatnił’ v negativistickej postave Lucifera v Madáchovej Tragédii človeka (11. 12. 1926), ktorú alternoval s českým hercom a režisérom Josefom Bezdíčkom. Kým ten rolu večného pokušitela ornamentálne dekoroval, Borodáč sa sústredil na vecné pretlmočenie myšlienok textu.

${ }^{14}$ Pozri [Bez autora]. Bačova žena. Od dr. Ivana Stodolu. Premiéra v SND 5. októbra 1928. In Slovák, 1928 , roč. 10, č. 225, s. 5, 6. 10. 1928.

${ }^{15}$ [Bez autora]. Z pôvodných slovenských noviniek sezony... In Slovenské dielo, 1929, roč. 1, č. 1, s. 59.

${ }^{16}$ Beta [Jindra Hušková]. Slovenská premiéra. In Slovenský denník, 1928, roč. 11, č. 229, s. 2, 6. 10. 1928.

${ }^{17}$ [Bez autora]. Bačova žena. In L'udová politika, 1928, roč. 4, č. 226, s. 4, 7. 10. 1928.

${ }^{18}$ GAŠPAR, T. J. Zo spomienok prvého slovenského dramaturga. In Slovenské divadlo, 1969, roč. 17, č. 1, s. 142 .

${ }^{19}$ Tamže. 


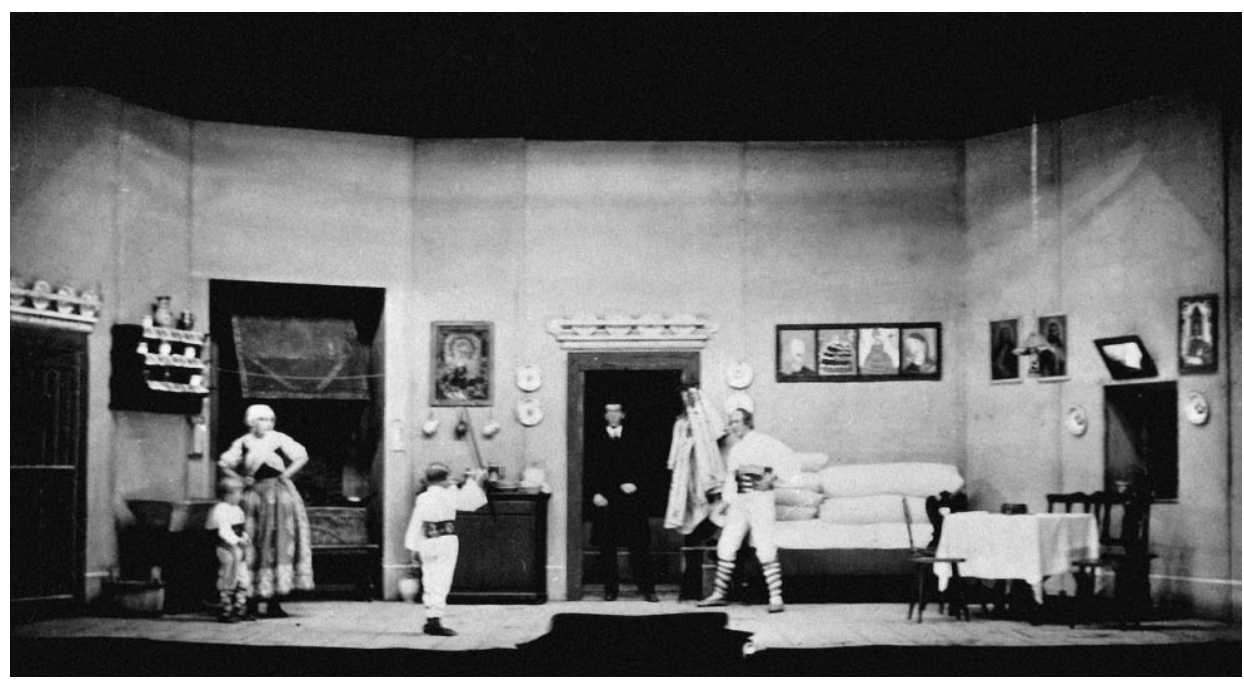

Ivan Stodola: Bačova žena. Slovenské národné divadlo, premiéra 4. 10. 1928. Réžia Janko Borodáč. Mária Jozefíková (Miško), Ol’ga Borodáčová Országhová (Eva), Viera Suchá (Ondrejko), Janko Borodáč (Ondrej), Andrej Bagar (Mišo). Foto archív SND.

Zároveň sa vyhol lacným hereckým efektom núkajúcim sa na základe metafyzickej podstaty úlohy. Možno predpokladat', že štylizovanejšie polohy vo výsostne básnickom texte a vo výpravnej režijnej interpretácii sa Borodáčovi stvárňovali prirodzenejšie než ponory do duševných polemík Alexeja Vronského či baču Ondreja. Kritika konštatovala, že „obsadenie ústrednej postavy celej hry (Lucifera) pri repríze pánom Borodáčom (...) pozdvihlo úroveň všetkých výkonností. Nebola to už karikatúra Lucifera, ale satan, ako ho musí mat' Madách, ironický duch večnej negácie, výsmešne vypočítavý a cynický. A aj t’ažké verše našli v Borodáčovi solídneho interpreta, ktorý vie, kde až siahajú hranice pravej výraznosti a kde by mohol byt’ kameň úrazu. ${ }^{20}$

S pribúdajúcimi povinnostami režiséra a od sezóny 1932/1933 aj šéfa samostatnej slovenskej činohry SND sa Borodáč postupne vzdával hereckého povolania. Na javisku vystupoval len ojedinele a výhradne vo vlastných réžiách. Na rozdiel od osobných ambícií v predchádzajúcom období, tentoraz boli dôvody objektívne: rozdelením ansámblu na autonómny slovenský a český súbor sa okruh slovenských režisérov zúžil len na Borodáča. Ojedinele mu na jeho vlastnú žiadost̉ režisérsky vypomáhali herci Andrej Bagar a Ján Jamnický, ktorým však ponúkal skôr podenkový repertoár na prilákanie stále absentujúceho slovenského publika. No treba povedat', že roly, ktoré si Borodáč pridel'oval, neboli iba epizódnymi figúrkami. Takmer vo všetkých prípadoch išlo o ideovo závažné úlohy, nesúce klúčovú myšlienku diela aj inscenácie: Herec v Gorkého hre Na dne (22. 11. 1932), Grazia v Chiarelliho groteske Tvár a maska (20. 11. 1934), Skala v Záborského Najdúchovi (5. 10. 1935), Ondrej Palčík v Tajovského Statkoch-zmätkoch (28. 10. 1936), Jochanan v Hviezdoslavovej tragédii Herodes a He-

\footnotetext{
${ }^{20}$ [Bez autora]. V našom S. N. D. In Slovák, 1926. Čiastočne identifikovaný článok sa nachádza v inscenačnej obálke Tragédia človeka, premiéra 11. 12. 1926. In Zbierka inscenácií, Divadelný ústav v Bratislave.
} 


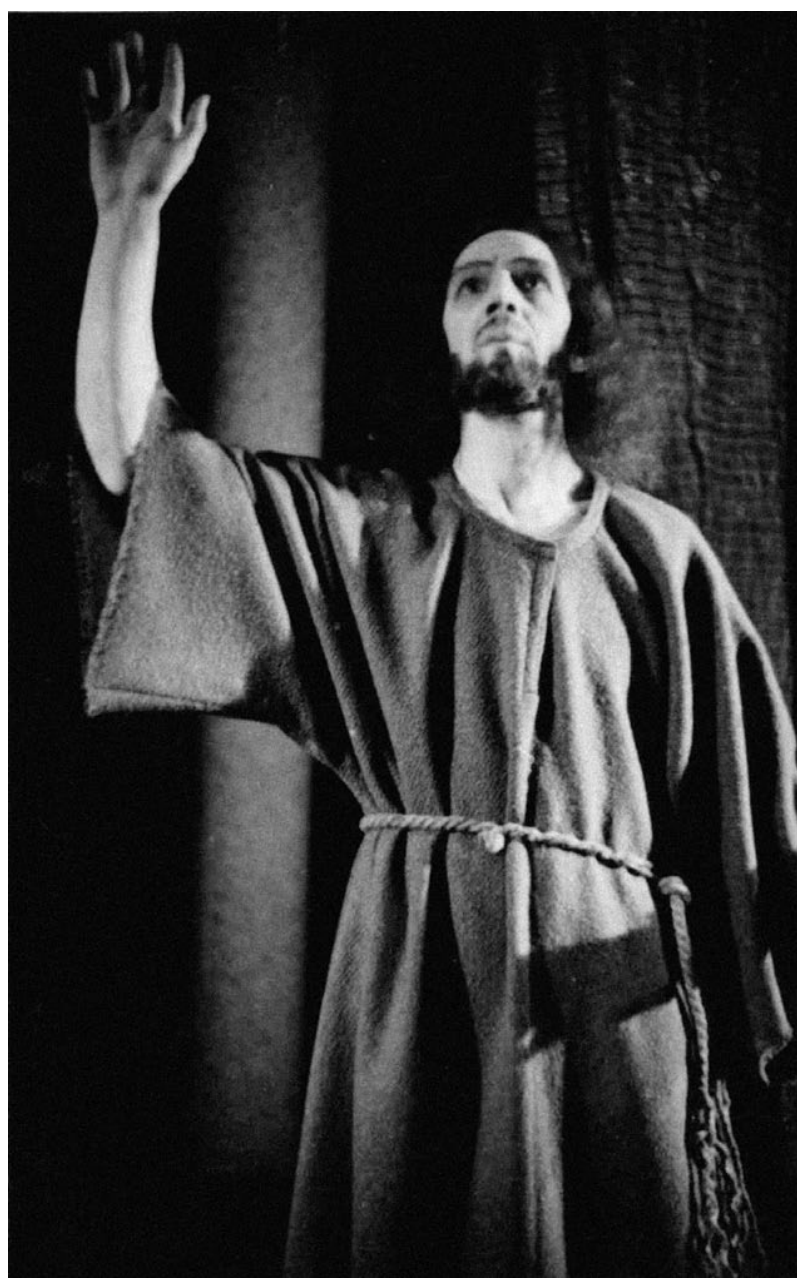

Pavol Országh Hviezdoslav:

Herodes a Herodias. Slovenské národné divadlo, premiéra 25. 9. 1937. Réžia Janko Borodáč. Janko Borodáč (Jochanan). Foto archív SND.

rodias (25. 9. 1937), Martin Stančík v Debnárových Chlapcoch na stráži (29. 10. 1938) či Uhorčík v Debnárovom Jurovi Jánošíkovi (5. 10. 1939). ${ }^{21}$

Z dnešného hl'adiska je t’ažké posúdit', či sa Borodáč ujal postáv z núdze (súbor stále nedisponoval väčším množstvom charakterových hercov, aj ked' bol po všetkých stránkach rozvinutejší než v prvom desatročí svojej česko-slovenskej existencie), alebo chcel cez dané roly sprostredkovat divákom osobné stanovisko. Napríklad Jochanan ponúka možnost' výkladu úlohy ako proroka a zástupcu utláčaného l'udu, ktorý sa pre svoju čestnost’ stáva obetou vládnucej moci. Preto možno vyslovit’ hypotézu, že Borodáč chcel týmto obsadením vypovedat’ niečo o svojom vnútornom (divadelnom) postavení. Jochanana podla recenzentov interpretačne chápal ako rebela, ktorý umrie v boji za pravdu. No v kritikách opät’ zaznelo, že Borodáč je predsa len

${ }^{21}$ Ján Debnár bol autorský pseudonym Janka Borodáča. 
lepším režisérom než hercom a že jeho prejav skízol skôr do predstavy asketického stredovekého mnícha. Paradoxne, kritici pozitívne upozorňovali na Jána Jamnického (v inscenácii stvárnil menšiu postavu Chuzu) - Borodáčovho oponenta v hereckom aj režijnom smerovaní, ktorý by rolu hlásatel'a nového poriadku Jochanana kreoval po verbálnej i neverbálnej stránke omnoho plastickejšie. Herecky bol totiž disponovaný pre prácu s veršom, boli mu blízke nadhl'ad i štylizácia, čo s daným typom drámy korešpondovalo viac než Borodáčova úporná snaha o psychologický prežitok.

Podobne nekonzistentne vyznela v Borodáčovej interpretácii aj postava skrachovaného Herca z Gorkého drámy Na dne. Ten nadnesene rozpráva o svojej divadelnej kariére, ale v skutočnosti si nevie spomenút’ ani na jednu repliku z rol, ktoré vraj kedysi s úspechom stvárňoval. „Pre Janka Borodáča, ktorý po dlhej dobe opät vystúpil, bola to príliš nesnadná úloha, nezvládol ju do detailov a suverenne a dôsledok toho bol, že ten najtragickejší okamih, kedy herec zúfalý nad svojou bezmocnostou a utrávenostou [autor mal asi na mysli slovo otrávenost' - pozn. K. M.] vybehne, aby sa obesil, vyznel celkom fraškovite. Nebol vyhraný, nebol zvládnutý a bol príliš krčovitý. “22 Aj pri tomto výkone sa kritici vyhýbali kategorickejšiemu zhodnoteniu, alibisticky zdôvodňujúc Borodáčove nedostatky jeho malou frekvenciou na javisku v poslednom období.

Podobne ako pri Jochananovi, aj pri Hercovi by sa dalo uvažovat’ o tom, či sa Borodáč obsadil do postavy so zámerom manifestovat’ svoj názor na dobu a (svoje) divadelné postavenie. Súčastou jeho osobnosti boli totiž danosti učitela, ktorý neustále mentoroval svoje okolie. Zároveň si ctižiadostivo zakladal na uznaní vlastnej pravdy a akceptácii významu svojej osobnosti. Popísané povahové vlastnosti sa premietali aj do jeho javiskovej tvorby. Túto hypotézu potvrdzujú slová Andreja Bagara: „Áno, Borodáč bol učitel'. A zostal ním po celý svoj život. So všetkými kladnými atribútmi tohto povolania, ale aj so všetkými zápornými, ktoré nás zavše na učiteloch mrzia. Borodáč po celý svoj život učil iných alebo seba. Učil hercov umeleckej čestnosti, zodpovednosti, charakternosti a disciplinovanosti. Bojoval od začiatku proti hereckému bohémstvu, proti javiskovej improvizovanosti. Učil hercov ctit’ si divadlo, slúžit mu s pokorou srdca, oddat’ sa mu celý. Týmto zásadám zostal verný až dodnes. No zavše zabúdal, že herci nie sú žiaci elementárnej školy, že sú to dospelí l’udia, ktorí kadečo môžu a vedia priniest’ do hry aj bez jeho učitel'ovania a povolenia. Niekedy sa trápne počúvali už hotovým hercom jeho široké a podrobné výklady o veciach tak základného charakteru, ktoré patria k abecede hereckej tvorby. No v ňom sa prebudil učitel' meštianky a bolo si teda treba vypočut' závažné traktáty, ktoré mal už každý začiatočník v malíčku. “23

Čo formovalo Borodáča ako herca? Vel'kú úlohu pravdepodobne zohrali nielen jeho pedagógovia na pražskom konzervatóriu - psychologický realista Jaroslav Hurt a pedagóg estetiky, budúci popredný pofebruárový presadzovatel’ socialistického realizmu Zdeněk Nejedlý, ale i divácky zážitok z inscenácií Kačalovovej skupiny MCHAT-u, ktoré videl hostovat’ v Prahe a onedlho v Bratislave. Práve dosiahnutie autentického prežitku bolo Borodáčovým hereckým (a neskôr i režijným) ciel’om, ku

${ }_{22}$ Jdv. [Josef Dvořák] Dve premiéry. Gorkij v slovenskom divadle. In Robotnícke noviny, 1932, roč. 29, č. 266, s. 4, 25. 11. 1932.

${ }^{23}$ BAGAR, A. Pamäti národného umelca Andreja Bagara. Nepublikovaný strojopis. In Knižnica Divadelného ústavu, s. 152. Sign. MB 2046 P. 


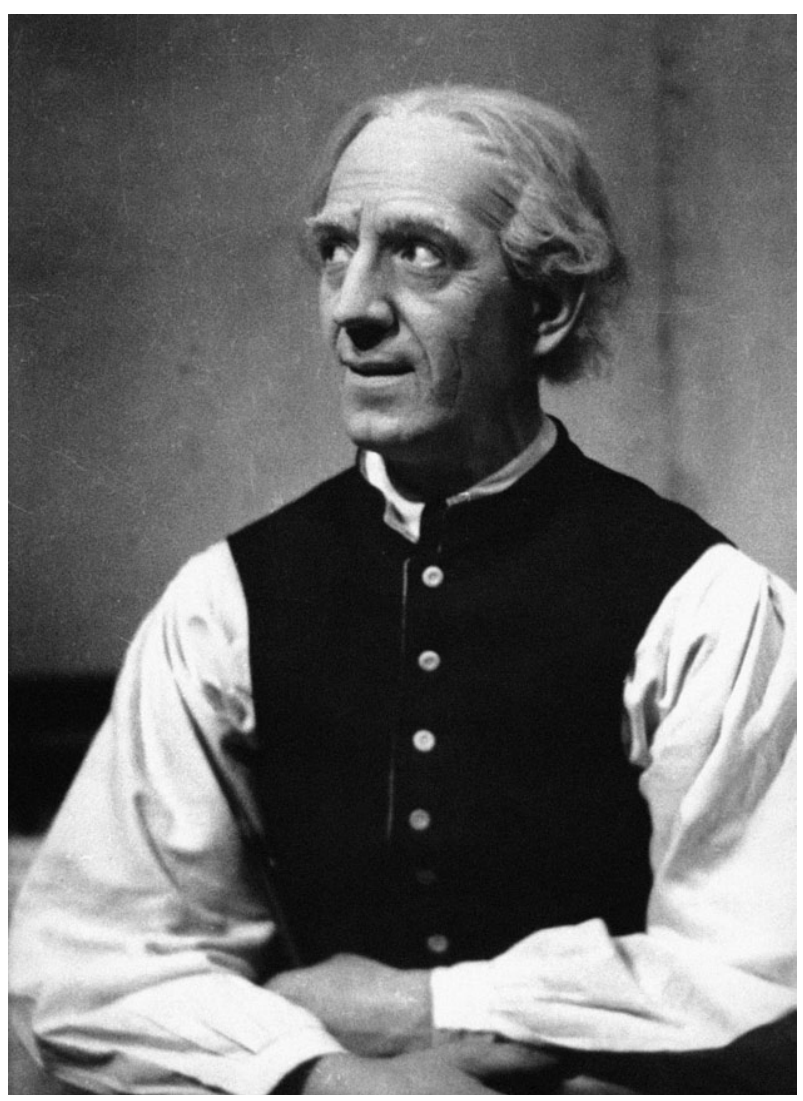

Jozef Gregor Tajovský: Statky-zmätky. Slovenské národné divadlo, premiéra 30. 10. 1928 (obnovená premiéra 28. 10. 1936). Réžia Janko Borodáč. Janko Borodáč (Štefan Palčík). Foto archív SND.

ktorému sa pokúšal dospiet’ svojou tvorbou a doviest' $\mathrm{k}$ nemu aj ostatných členov činoherného súboru SND. No zabraňovali mu v tom nielen neadekvátne umelecké, prevádzkové a finančné podmienky slovenského profesionálneho divadla, ale aj jeho slabá zorientovanost’ v teoretických základoch tejto divadelnej metódy či mantinely jeho divadelného talentu.

Borodáč sa ako neústupčivý ctitel’ iluzívneho divadla Konstantina Sergejeviča Stanislavského snažil do vlastnej hereckej praxe aplikovat' učenie vel'kého ruského divadelníka. Do osobného diára si už v roku 1925 zapísal motto: „Nie hrat', ale žit’ na javisku. ${ }^{24}$ No v skutočnosti ostával príliš na povrchu a upadal do deklamačného pátosu. Dva zachované filmy, Jánošík a M. R. Štefánik (oba z roku 1935), kde Borodáč stvárnil vedlajšie postavy, ho zachytávajú ako herca príliš ilustratívneho, výrazovo prepiateho a emočne nezodpovedajúceho atmosfére sekvencií. Oba filmy sú jedinými záchytnými bodmi, vd’aka ktorým môžeme s odstupom rokov hodnotit jeho hereckú disponovanost', hoci do úvahy treba zobrat' prirodzené i technické rozdielnosti divadelného a filmového herectva. Borodáč si podl'a všetkého v priebehu desatročí

${ }^{24}$ BORODÁČ, J. Osobný zápisník (1925). In Archív Divadelného ústavu Bratislava, archívna škatul’a $1 \mathrm{~F} 222$ 
uvedomoval svoju neschopnost' plynulejšie herecky preniknút' do metódy psychologického realizmu, ktorú ako režisér presadzoval a cizeloval, a preto na hereckú kariéru postupne rezignoval.

Asi najautentickejšie zhodnotil jeho herectvo režisér Jozef Budský, ktorý od roku 1935 hrával v českej činohre SND a mohol byt’ teda svedkom Borodáčových posledných výkonov. Nehovoriac o tom, že sa medzi rokmi 1939 a 1945 stal tažiskovým hercom Borodáčových inscenácií, ked’ o. i. stvárnil titulnú postavu v Sofoklovom Oidipovi, Viktora Žiaranského zo Stodolovej Maríny Havranovej či Wolframa z Bezekovej Klietky. „Ján Borodáč nebol dobrým hercom. Dokonca bol hercom vel’mi zlým, a rád sa ako herec realizoval aspoň v záskokoch za ochorelých hercov, alebo aspoň ako režisér rád hercom predohrával. Nechcel by som ani v najmenšom vzbudit podozrenie, že jeho režijna tvorba bola obrazom jeho herectva. To v nijakom prípade. A predsa spôsob jeho herectva, $\mathrm{v}$ jeho cítení, nie realizovaní, bol v režijnej tvorbe prítomný. “25

Janko Borodáč ukončil svoju hereckú kariéru v roku 1939 a na javisko sa vracal už len z nutnosti (napr. pre záskoky za indisponovaných kolegov). Plnohodnotne sa sústredil na režijnú, administratívnu a pedagogickú činnost'. Ako pedagóg si postupne vychoval nasledovníkov, takže ako herec už nebol nepostrádatel'ný. Podl'a všetkého sa po takmer dvoch desatročiach a približne 105 stvárnených úlohách nemal problém vzdat' hereckého povolania, ved' už od roku 1924, ked' začal režírovat', si na prednú stranu svojich osobných diárov (pravdepodobne hrdo) písal len povolanie: režisér.

\section{Borodáč ako pedagóg hereckej tvorby}

Ak chceme zhodnotit prínos Janka Borodáča pre slovenské herecké umenie, nemožno popri jeho vlastnej interpretačnej činnosti vynechat’ jeho pedagogickú úlohu. Už v Marške zaznamenávame dôležitý moment tejto Borodáčovej práce. Od vzniku SND totiž kultúrni publicisti vyzývali k poslovenčeniu divadla a v prípade, že sa hralo po slovensky (čo bolo v SND i v Marške skôr výnimkou), k používaniu spisovnej slovenčiny. Preto sa kládol dôraz na gramatiku, kalilógiu a fonetiku. Borodáčovi kolegovia, Karel Balák v osobnom denníku ${ }^{26}$ aj Andrej Bagar vo svojich nepublikovaných Pamätiach ${ }^{27}$, jednotne spomínajú na to, ako Janko Borodáč s Ol'gou Országhovou učili českých kolegov v Marške pravidlá slovenčiny a správnu výslovnost'. Borodáčovo herectvo a neskôr aj režijná prax sa totiž zakladali na slove a jeho technickej a emocionálnej artikulácii. Pritom on sám sa do konca života nedokázal zbavit jemného východoslovenského prízvuku.

Podstatným Borodáčovým prínosom pre slovenské divadelníctvo prvej polovice 20. storočia bolo založenie divadelného školstva. Na bratislavskej Hudobnej škole pre Slovensko otvorili v roku 1925 prvý ročník dramatického odboru, čím vznikla Hudobná a dramatická akadémia pre Slovensko (d’alej len HADAPS). Borodáč tu pedagogicky pôsobil až do roku $1941^{28}$ a v učebných osnovách sa opieral najmä o skúsenosti z pražského konzervatória. Jedna z prvých absolventiek odboru, Ružena Po-

${ }^{25}$ BUDSKÝ, J. Dúhové oblúky [Pamäti.]. Nepublikovaný strojopis, s. 365/337. In Osobný fond Jozefa Budského. Archív Divadelného ústavu Bratislava.

${ }^{26}$ Viac pozri PAŠUTHOVÁ, Z - HUDEC, R. Marška. Denník Karla Baláka.

${ }^{27}$ Viac pozri BAGAR, A. Pamäti národného umelca Andreja Bagara.

${ }^{28} \mathrm{~V}$ tomto roku sa HADPAS pretransformoval na Štátne konzervatórium. 


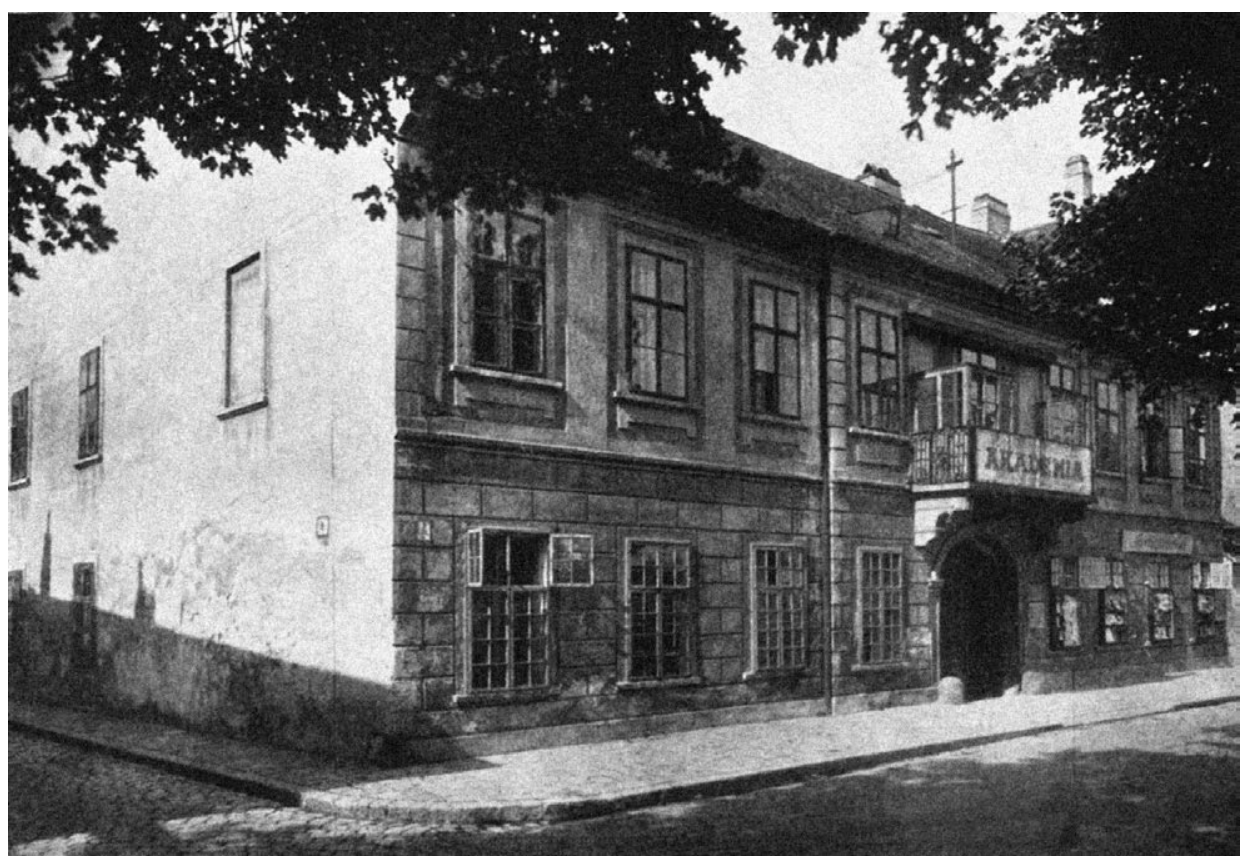

Budova Hudobnej a dramatickej akadémie pre Slovensko v dvadsiatych rokoch 20. storočia. Foto archív SND.

rubská, napísala: „V triede profesora Janka Borodáča sa hlavný dôraz kládol na jasné zretel'né artikulovanie, na citlivé narábanie slovom a jeho emočné prežívanie. Praktické cvičenia sme absolvovali väčšinou recitovaním básní, monológov a dialógov. ${ }^{29}$ V inom spomienkovom článku je aj kritickejšia, ked’ poznamenáva: „V počiatočných rokoch mojej divadelnej práce sa pristupovalo k dramatickým dielam, ak to tak môžem nazvat’ skôr z idealistického svetonázoru. Približne asi takto: ,nešpekulovat', ale cítit”, ,mat' lásku k veci' atd'. "30 Herečka tu mala na mysli Borodáčov rigorózny prístup, ked’ odmietal akýkol'vek herecký nadhl’ad nad postavou či stvárnenie úlohy nerealistickými, teda štylizovanými prostriedkami. V školských laviciach a následne i v praktickom živote sa Borodáč takto snažil priblížit k svojmu divadelnému vzoru, Stanislavskému, aj ked' pre osvojenie zmyslu jeho poetiky nemal spočiatku dostatok primárnej literatúry. ${ }^{31}$ Ale ako sám v roku 1954 povedal, pri tvorbe sa Stanislavského

\footnotetext{
${ }^{29}$ PORUBSKÁ, R. Moje spomienky. In Slovenské divadlo, 1955, roč. 3, č. 2, s. 160 - 161.

${ }^{30}$ PORUBSKÁ, R. Rozpomienky na Viktora Šulca. In Slovenské divadlo, 1958, roč. 6, č. 3, s. 237.

${ }^{31}$ Borodáč v niekol'kých publicistických zdrojoch tvrdí, že Stanislavského knihu Môj život v umení obdržal už v roku 1926. Ďalšie publikácie ako Moja výchova k herectvu, Umelecké zápisky a besedy, Z minulosti Nemiroviča mal možnost’ získat’ až v polovici tridsiatych rokov. Viac pozri BORODÁČ, J. Umelecká a životná sila našich klasikov. Zo zápiskov laureáta štátnej ceny Janka Borodáča. In Kultúrny život, 1952, roč. 7, č. 36, s. 7. Teatrologička Nadežda Lindovská na základe nového výskumu považuje za pravdepodobnejšie, že sa k emblémovému dielu Stanislavského Môj život v umení dostal až okolo roku 1937. Viac pozri LINDOVSKÁ, N. Moskva, rok 1940: Mikuláš Gacek a Vladimír Nemirovič-Dančenko. Archívne stopy slovensko-ruských divadelných vztahov, s. 154 - 173. In KNOPOVÁ, E. (ed.). Divadlo a dráma v kontextoch nepokojnej Európy. Banská Bystrica : Akadémia umení, 2019. Borodáč však o získaní knihy v roku 1926 hovorí
} 
metódy nedržal deskriptívne, slúžila mu len ako vol’ná inšpirácia: „Siahol som po knihe Konstantina Sergejeviča, ked' som ju ako umelec potreboval - ale nikdy nememoroval som jej obsah ako z učebnice. Pracoval som podla pravidiel realizmu, ale vždy tak, ako mi to umelecky diktoval. V umení niet problému jednoduchosti a komplikovanosti - je len problém pravdivosti a falošnosti. ${ }^{\text {(32 }}$

$\mathrm{V}$ počiatočnej fáze pedagogickej kariéry sa doslovne riadil týmito zásadami. Mladých adeptov herectva učil najmä umeniu prežívania, nie podl’a Stanislavského (i ked' vplyv jeho metódy, či už z primárnych alebo prevzatých vzorov, tu bol samozrejme prítomný), ale podla intencií iluzívneho divadla. Podobne ako v režisérskej činnosti, aj v pedagogickej praxi boli pre neho podstatné dva aspekty - psychologická pravdivost’ a zrozumitel’ná vrava, ktorá sa napriek technickej presnosti neprieči prirodzenému l’udskému prejavu. Jeho študent Mikuláš Huba, herec a neskôr sám pedagóg hereckej tvorby, po rokoch bližšie charakterizoval Borodáčov spôsob výučby: „Pedagogická metóda Janka Borodáča mala vždy v jednu spojené dve črty. Všeobecnú a odbornú. Tou všeobecnou boly požiadavky hereckej etiky, ktorej sa domáhal vel'mi pádne a neváhal prísne, opravdivo, rozhorčene a vyčerpávajúco karhat' naše poklesky, pokial išlo o disciplínu a vážny zástoj k divadlu a k našej študijnej práci. Tou odbornou boly praktické rady, vyplývajúce z daných úloh a cvičení, podopreté zavše teoretickým diktátom. V teórii sa preberal dost’ podrobne Diderotov Herecký paradox. Borodáčova výchova v škole sa niesla v najužšom kontakte s divadelnou produkciou a často sa na svojich hodinách kriticky vracal k tomu, čo sa našim hercom na javisku podarilo, alebo čo nebolo ,dotiahnuté' a správne realisticky podopreté a stvárnené. Celá Borodáčova herecká výchova smerovala k praxi; k tým úlohám, ktoré čakaly jeho odchovancov v javiskovej umeleckej práci. Pri tejto práci vedel byt náš učitel' vel'mi trpezlivý a neúnavný. Opravoval slovo za slovom, gesto za gestom. Diskutoval, požadoval, objasňoval i predhrával. Tento výchovný smer uplatňoval tým skôr, že mnohí z mladých adeptov umenia boli zapojení do aktívnej produkcie v činohre SND, čo nieslo so sebou nielen niektoré výhody, ale aj mnohé nebezpečenstvá a čo bolo diktované potrebami malého a početne slabého súboru. “33

Borodáč sa počas vyučovacieho procesu pokúšal v mladých adeptoch herectva prebudit skutočný, t. j. psychologicky zdôvodnitel'ný cit. Teatrológ Marián Mikola ho charakterizoval ako pedagóga a najmä režiséra, ktorému treba „priznat' schopnost' viest' herca $\mathrm{k}$ náročnému psychologickému portrétovaniu, $\mathrm{k}$ modelovaniu postavy, ktoré vyviera z bohatého citového prežitku“. ${ }^{34}$ Od hercov vyžadoval osvojenie si realistických podtextov, vycizelovanie psychických motivácií, ciel’ovo jasné konanie a prostý, no zároveň prirodzený pohyb po javisku. Preto tvrdenie Mikuláša Štefana Gojdu, týkajúce sa Borodáčovej režisérskej činnosti, možno vztiahnut’ aj na jeho peda-

už v rozhovore z roku 1944. Pozri BOR, J. E. Rozhovor so zakladatelom slovenskej profesionálnej réžie, s. 35. In SLÁDEČEK, J. Prolegomena : k štúdiu dejín slovenskej divadelnej réžie 20. storočia. Banská Bystrica : Akadémia umení, 2013. Je teda otázne, prečo by si už v tomto období údaj o získaní publikácie nepamätal alebo ho chcel z nejakého dôvodu zahmlievat'.

${ }^{32}$ BORODÁČ, J. Stanislavského teória prakticky. Prednesené na konferencii o odkaze K. S. Stanislavského. In Divadlo,1954, roč. 5, č. 8, s. 731.

${ }^{33}$ HUBA, M. Žriedla scénického realizmu Jána Borodáča, s. 150 - 151. In RAMPÁK, Z (ed.). V službách slovenského divadla : Sborník k 60. narodeninám Jána Borodáča, laureáta Štátnej ceny. Martin : Matica slovenská, 1952.

${ }^{34}$ MIKOLA, M. Roky 1949 - 1956, s. 99. In RAMPÁK, Z. - MIKOLA, M. - MRLIAN, R. Dvadsat’ rokov Slovenského činoherného divadla : (1945 - 1965). Bratislava : Slovenské pedagogické nakladatel’stvo, 1966. 


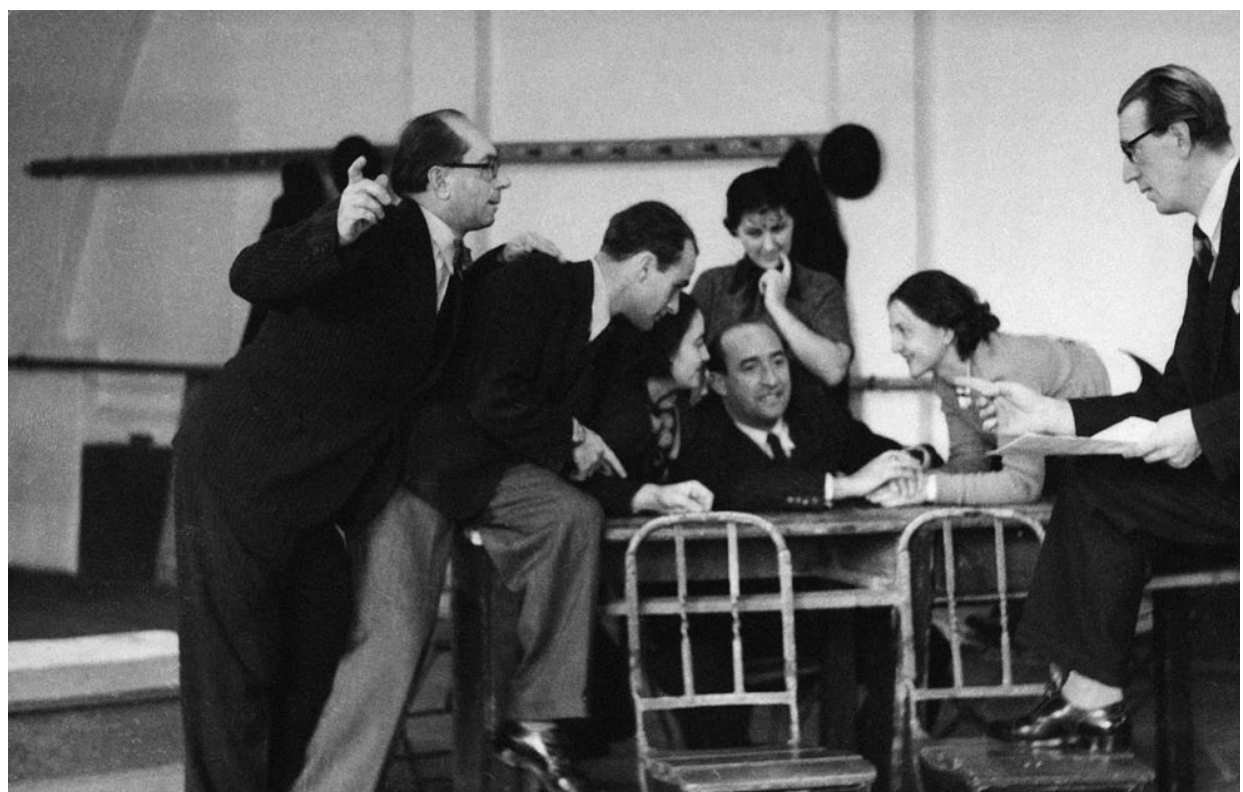

Janko Borodáč pri režírovaní inscenácie hry Jána Grežu Barbora. Slovenské národné divadlo, premiéra 5. 12. 1936. Zl’ava Jozef Kello, Štefan Figura, Mária Bancíková, Andrej Bagar, Lea Juríčková, Mária Schwingerová, Janko Borodáč. Foto archív SND.

gogické pôsobenie: „Bol jedným z tých režisérov, ktorí hercovi vnucovali svoje myslenie, často i psychofyzické konanie, gesto, mimiku, chôdzu, pohyb, pohlad. Borodáč totiž presne vedel, čo chce a do dôsledku uskutočňoval svoju fantáziu, predstavu, svoj inscenačný zámer často bez ohl'adu na hercovu mienku o jeho zámere. Borodáčove skúšky - to bola drezúra, presnost', chodenie po špičkách za scénou a hlavne disciplína (...). “ ${ }^{\text {"35 }}$ Rigoróznost’ Borodáčovej režijno-pedagogickej práce potvrdzujú aj osobné spomienky herečiek Zdeny Gruberovej a Evy Kristinovej, ktoré s ním spolupracovali na prelome pätdesiatych a šest’desiatych rokov. Borodáč usmerňoval hercov do presne určených dráh a vel’mi prísne im predpisoval všetky reakcie i emócie. Konkrétne výrazové prostriedky, t. j. formálnu stránku stvárnenia, však už podl'a Kristinovej ponechával na hereckom predstavitel'ovi.

Nekritické pestovanie iluzívno-realistickej metódy a vol'né interpretovanie učenia Stanislavského v pedagogickej i režijnej práci Janka Borodáča považovali kritici za retrográdne už v medzivojnových rokoch. Problém s tým mali aj študenti, ktorí svojím hereckým naturelom i osobným názorom inklinovali k tvárnejšiemu vnímaniu divadelného umenia. Medzi nich patrila už citovaná Ružena Porubská, ktorá v roku 1934 prestúpila od archaického šéfa slovenskej činohry Borodáča do českého súboru vedeného modernistickým Viktorom Šulcom, alebo Ján Jamnický, ktorý bol od školských čias jasným pedagógovým antipólom. Jamnický po rokoch stručne zhrnul diferenciu ich umeleckých naturelov: „On vychádzal, povedzme z ochotníctva a zo

${ }^{35}$ GOJDA, M. Š. Dvadsat' rokov činohry ŠD. In ZBOROVJAN, J. (ed.). 20 rokov ŠD v Košiciach. Košice : Východoslovenské vydavatel’stvo, 1965, s. 33. 
Stanislavského, tak ako ho on pochopil, a ja som vychádzal práve tak z ruského divadla, z avantgardného divadla, zo Stanislavského, ale aj zo všetkých avantgardných divadiel, napríklad z českého avantgardného divadla. A už ako študent v druhom ročníku školy som sa vedel názorove jasne odlišovat’ a sme sa aj odlišovali.“" ${ }^{36}$

Borodáč po návrate z košického divadla, v ktorom v rokoch 1945 - 1953 zastával post riaditel'a, vyučoval v rokoch 1953 - 1963 na Vysokej škole múzických umení, v období 1953 - 1958 tu vykonával aj funkciu dekana Divadelnej fakulty. Podla spomienok Štefana Kvietika sa Borodáčova pedagogická metóda nelíšila od tej, ktorou vzdelával už citovaných Ruženu Porubskú, Jána Jamnického či Mikuláša Hubu na HADAPS-e: „Tu sme sa pokúšali v rozličných etudách zvládnut rozmanité okolnosti, brat' na zretel' všetko, čo nás mohlo viest' k pravdivému konaniu, $\mathrm{k}$ vnímaniu a pochopeniu situácie, vztahov, atmosféry a iných faktorov, aby sme zdôvodnili svoju exis-

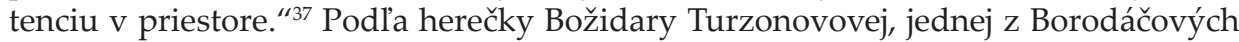
posledných študentiek, mnohí až neskôr pochopili, že práve on dával študentom herecké základy, na ktorých mohli stavat. „Jeho hodiny boli vel’mi precízne. Chvílami nám bol až komický, ale neskôr, ked’ som sa sama stala pedagogičkou, tak som si uvedomila, že nás naučil nesmierne dôležité veci. Neboli to nijaké intelektuálne piruety a brilancie, ale hovoril nám abecedu javiska, abecedu remesla. Doteraz si pamätám ako nám neustále opakoval - zrozumitel'nost', zrozumitel'nost', zrozumitel'nost'. " ${ }^{38}$ No na rozdiel od prvých rokov výučby, ktoré viac formovala prax než odborná literatúra, na hodinách hereckej tvorby na VŠMU už Borodáč prednášal Stanislavského metódu z existujúcich slovenských prekladov jeho diel.

Borodáčova herecká skúsenost’ z medzivojnového obdobia sa automaticky premietala do jeho pedagogického pôsobenia. Ako povedal d’alší z jeho študentov, herec František Zvarík: „Borodáč nás učil po javisku chodit’, Jamnický tancovat.." Pántik toto vyjadrenie mierne varioval: „Borodáč nás učil spočítavat’ a odpočítavat, Jamnický násobit’ a delit." ${ }^{40}$ Borodáčovo herectvo bolo skutočne založené na psychologických podtextoch a realistickej autentickosti. No podla dostupných materiálov, on sám dokázal postavu herecky uchopit iba z formálneho, nie z obsahového hl'adiska. Rozumel jej psychike, ale nevedel ju na javisku presvedčivo pretlmočit, takže výsledkom boli vo väčšine prípadov len neživé figúry. Zato z pozície režiséra a pedagóga dokázal výrečnejšie sprostredkovat’ svoje predstavy a u hercov docielit’ ucelené psychologicko-realistické kreácie.

${ }^{36}$ Vystúpenie Dr. Jamnického pred komisiou pre mimosúdne rehabilitácie. In SLÁDEČEK, J. JUDr. Ján Jamnický - spoved' režiséra: (Dokumenty) [I. zväzok]. Bratislava : Národné divadelné centrum, 1998, s. 230.

${ }^{37}$ ČMAJ, J. Štefan Kvietik : život bez opony. Bratislava : Slovart, 2009, s. 99.

${ }^{38} \mathrm{Z}$ osobného rozhovoru autora štúdie s Božidarou Turzonovovou, nahrané v Divadelnom ústave, Bratislava, 22. 10. 2014.

${ }^{39}$ LAJCHA, L. Silueta generácie : Osobnosti činohry SND. Bratislava : Divadelný ústav 2013, s. 345.

${ }^{40}$ Pozri Ján Borodáč - dokument. Spomienkový večer v SND, 1992. Audiovizuálny záznam uložený v Mediatéke Divadelného ústavu. 


\section{AN UNKNOWN (ACTOR'S) FACE OF JANKO BORODÁČ}

\section{Karol MIŠOVIC}

When reflecting on the work of Janko Borodáč, the founding personality of Slovak theatre, the greatest emphasis is rightly placed on his directing, dramaturgical, and directorial activities. Aside from that, Borodác had also been an active member of the Slovak National Theatre drama ensemble for more than twenty years, where he enjoyed a prominent position. The aim of the study is to present not only the overlooked, marginalised even, perception view of his actor's profile, but also to characterise the context of the chaotic operation of SND in its early years, in which the first generation of Slovak actors worked. Borodáćs s work as a pedagogue is also related to acting. Thanks to him, drama as a self-contained field of study was established at the Music School in Bratislava, the first of its kind in Slovakia, where he taught new generations of Slovak artists. As in directing and acting, in his teaching, too, he encouraged his students to familiarise themselves with a psychological-realistic method and he was consistent in disapproving of any manifestation of anti-illusionary stylisation.

Štúdia je príspevkom k projektu APVV č. 15-0764 Slovenské divadlo a súčasná európska divadelná kultúra - kontinuita a diskontinuita.

\section{LITERATÚRA}

BAGAR, Andrej. Pamäti národného umelca Andreja Bagara. Nepublikovaný strojopis. In Knižnica Divadelného ústavu, sign. MB 2046 P. 318 s.

Beta [Jindra Hušková]. Druhý večer Tolstého osláv. In Slovenský denník, 1928, roč. 8, č. 198, s. 3, 16. 9. 1928.

Beta [Jindra Hušková]. Slovenská premiéra. In Slovenský denník, 1928, roč. 11, č. 229, s. 2, 6. 10. 1928.

[Bez autora]. Bačova žena. In Ludová politika, 1928, roč. 4, č. 226, s. 4, 7. 10. 1928.

[Bez autora]. Bačova žena. Od dr. Ivana Stodolu. Premiéra v SND 5. októbra 1928. In Slovák, 1928, roč. 10, č. 225, s. 5, 6. 10. 1928.

[Bez autora]. Herodes a Herodias. In Slovenský denník, 1925, roč. 8, č. 271a, s. 3, 29. 11. 1925.

[Bez autora]. V našom S. N. D. In Slovák, 1926. Čiastočne identifikovaný článok sa nachádza v inscenačnej obálke Tragédia človeka, premiéra 11. 12. 1926. In Zbierka inscenácií, Divadelný ústav v Bratislave.

[Bez autora]. Z pôvodných slovenských noviniek sezony... In Slovenské dielo, 1929, roč. 1, č. 1, s. 59.

BOR, J. E. Rozhovor so zakladatel'om slovenskej profesionálnej réžie, s. 19 - 44. In SLÁDEČEK, Ján. Prolegomena : $k$ štúdiu dejín slovenskej divadelnej réžie 20. storočia. Banská Bystrica : Akadémia umení, 2013. 745 s. ISBN 978-80-8955-26-0.

BORODÁČ, Ján. Stanislavského teória prakticky. Prednesené na konferencii o odkaze K. S. Stanislavského. In Divadlo,1954, roč. 5, č. 8, s. 726 - 732.

BORODÁČ, Janko. Spomienky. Bratislava : Národné divadelné centrum, 1995. 344 s. ISBN 80-85455-07-2.

BORODÁČ, Janko. Umelecká a životná sila našich klasikov. Zo zápiskov laureáta štátnej ceny Janka Borodáča. In Kultúrny život, 1952, roč. 7, č. 36, s. 7.

BUDSKÝ, Jozef. Dúhové oblúky [Pamäti.]. Nepublikovaný strojopis. In Osobný fond Jozefa Budského uložený vo Verejnom špecializovanom archíve Divadelného ústavu, Bratislava. 406/438 s. 
ČERNÝ, František. Otázky divadelní režie. Praha : Melantrich, 1988. 237 s.

ČOMAJ, Ján. Štefan Kvietik : život bez opony. Bratislava : Slovart, 2009. 243 s. ISBN 978-80-8085992-3.

Jdv. [Josef Dvořák] Dve premiéry. Gorkij v slovenskom divadle. In Robotnícke noviny, 1932, roč. 29, č. 266, s. 4, 25. 11. 1932.

GAŠPAR, Tido J. Zo spomienok prvého slovenského dramaturga. In Slovenské divadlo, 1969, roč. 17, č. 1 , s. $132-145$.

GOJDA, Mikuláš Štefan. Dvadsat' rokov činohry ŠD, s. 29 - 43. In ZBOROVJAN, Julo (ed.). 20 rokov ŠD v Košiciach. Košice : Východoslovenské vydavatel'stvo, 1965. $315 \mathrm{~s}$.

H.G. [Hana Gregorová]. Nútená svadba. 1924. Čiastočne identifikovaný článok sa nachádza v inscenačnej obálke Juraj Dandin/Nútená svadba, premiéra 18. 9. 1924. In Zbierka inscenácií, Divadelný ústav v Bratislave.

H.G. [Hana Gregorová]. Hviezdoslavov Herodes. In Robotnícke noviny, 1925, roč. 22, č. 299, s. 5, 29. 11. 1925.

HUBA, Mikuláš. Žriedla scénického realizmu Jána Borodáča, s. 141 - 154. In RAMPÁK, Zoltán (ed.). V službách slovenského divadla : Sborník k 60. narodeninám Jána Borodáča, laureáta Štátnej ceny. Martin : Matica slovenská, 1952. 174 s.

KÜHN, L'udevít. Slovenské národné divadlo. In Slovenský svet, 1921, roč. 1, č. 29 - 30, s. 21 - 22, 13. 11. 1921.

LAJCHA, Ladislav. Silueta generácie : Osobnosti činohry SND. Bratislava : Divadelný ústav 2013, 583 s. ISBN 978-80-89369-41-6.

LINDOVSKÁ, Nadežda. Moskva, rok 1940: Mikuláš Gacek a Vladimír Nemirovič-Dančenko. Archívne stopy slovensko-ruských divadelných vztahov, s. 154 -173. In KNOPOVÁ, Elena (ed.). Divadlo a dráma v kontextoch nepokojnej Európy. Banská Bystrica : Akadémia umení, 2019. 371 s. ISBN 978-80-8206-026-6.

MAŤAŠÍK, Andrej. Cesty slovenského herectva. In Slovenské divadlo, 2008, roč. 56, č. 1, s. 12 - 20. ISSN 0037-699X.

MIKOLA, Marián. Roky 1949 - 1956, s. 75 - 107. In RAMPÁK, Zoltán - MIKOLA, Marián MRLIAN, Rudolf. Dvadsat' rokov Slovenského činoherného divadla : (1945 - 1965). Bratislava : Slovenské pedagogické nakladatel'stvo, 1966.

MIŠOVIC, Karol. Ján Borodáč a jeho prvé kroky v živote i v divadle. In Slovenské divadlo, 2017, roč. 65, č. 2, s. $101-120$. ISSN 0037-699X.

MRLIAN, Rudolf. Dvadsat' rokov Slovenského činoherného divadla : (1945 - 1965). Bratislava : Slovenské pedagogické nakladatel'stvo, 1966. $186 \mathrm{~s}$.

MISTRÍK, Miloš. Analýzy hereckej syntézy. Bratislava : Thália-press, 1995. 172 s. ISBN 80-8571824-3.

PAŠUTHOVÁ, Zdenka - HUDEC, Rudolf. Marška. Denník Karla Baláka. Bratislava : Divadelný ústav, 2011. 271 s. ISBN 978-80-89369-32-4.

PORUBSKÁ, Ružena. Moje spomienky. In Slovenské divadlo, 1955, roč. 3, č. 2, s. 158 - 169.

PORUBSKÁ, Ružena. Rozpomienky na Viktora Šulca. In Slovenské divadlo, 1958, roč. 6, č. 3, s. $237-243$.

SLÁDEČEK, Ján. JUDr. Ján Jamnický - spoved' režiséra : (Dokumenty) [I. zväzok]. Bratislava : Národné divadelné centrum, 1998. 379 s. ISBN 80-85455-60-9.

Karol Mišovic

Ústav divadelnej a filmovej vedy CVU SAV

Dúbravská cesta 9

84101 Bratislava

e-mail: karol.misovic@savba.sk 